Jurnal Manajemen Indonesia Vol. 21(2), pp. 191-197, 2021)

Online ISSN : 2502-3713 | Print ISSN : 1411-7835

This Journal is available in Telkom University online Journals

Jurnal Manajemen Indonesia

Telkom

Journal homepage: journals.telkomuniversity.ac.id/ijm

\title{
Effect of Relationship Marketing and Competitive Advantage on Marketing Performance (Survey on Cellphone Customers in Bandung)
}

\author{
Usep Deden Suherman ${ }^{1}$ \\ ${ }^{1}$ Faculty of Economics and Islamic Business, UIN SGD Bandung, Indonesia
}

\begin{abstract}
This research aims to determine the effect of relationship marketing and competitive advantage on marketing performance partially and simultaneously. This research uses a quantitative method using a questionnaire. The sample technique used is purposive sampling technique. The data analysis technique used is multiple regression analysis. The results of this study illustrate that relationship marketing partially has a positive and significant impact on marketing performance. Furthermore, partial competitive advantage has a positive and significant effect on marketing performance. Meanwhile, simultaneous relationship marketing and competitive advantage has an influence on marketing performance.
\end{abstract}

Keywords-- Relationship Marketing, Competitive Advantage, Marketing Performance

\begin{abstract}
Abstrak
Penelitian ini bertujuan untuk mengetahui pengaruh relationship marketing dan keunggulan bersaing terhadap kinerja pemasaran secara parsial maupun simultan. Penelitian ini menggunakan metode kuantitatif dengan menggunakan kuesioner. Teknik sampel yang digunakan adalah teknik purposive sampling. Sedangkan teknik analisis data yang digunakan adalah analisis regresi berganda. Hasil penelitian ini menggambarkan bahwa pemasaran relasional secara parsial berpengaruh positif dan signifikan terhadap kinerja pemasaran. Selanjutnya, keunggulan bersaing parsial berpengaruh positif dan signifikan terhadap kinerja pemasaran. Sedangkan secara simultan pemasaran relasional dan keunggulan bersaing memiliki pengaruh terhadap kinerja pemasaran.
\end{abstract}

Kata Kunci -- Pemasaran Relasi, Keunggulan Kompetitif, Kinerja Pemasaran

\section{INTRODUCTION}

The very fast changing environment in business causes competition for companies to become increasingly sharp. The result of this sharp competition is the occurrence of Hyper-competition. Hyper-competition is the result of dynamic strategic maneuvers among global and innovative competitors. This condition is marked by competition that continues to increase rapidly based on price-quality positioning, competition to create new knowhow and build first-mover advantages, and competition to protect or attack an established product or market.

The phenomenon of intense competition between cellphone brands has made companies that have a cellphone business aware of the need in order to increase the use of organizational resources to keep a business going. Phones that have a strong brand, of course, can dominate the market and even expand the market easily. Besides relying on strong brands, mobile phone entrepreneurs are also trying to design and strategize to win in the competition. The strategy that can be used is relationship marketing. According to Nagasimha (2008: 4) suggests that relationship marketing is related to Trust and Communication. In fact, the current customer's trust in Chinese cell

Article info

Received (10/11/2019)

Revised (08/06/2020)

Accepted (28/07/2021)

Corresponding_author: usepds@upi.ac.id

DOI: 10.25124/jmi.v21i2.2293

Copyright@2021. Published by School of Economics and Business - Telkom University 
phones is still in doubt. This is because the quality of Chinese cell phones is still questionable by customers, so it is necessary to build a trust in Chinese cell phones. Customer trust in a brand is measured by always using the same products and believing in product quality. Like Nagasimha, Kotler and Keller (2009: 50) suggest that relationship marketing is related to reactive and proactive marketing. Reactive is related to service to customers by making contact with customers. Meanwhile, proactive marketing deals with how to create long-term relationships in order to get something better. The development of this relationship marketing can be viewed from table 1 which describes the proactive marketing of Branded cellphones and Chinese cell phones.

Table 1 Proactive Marketing of Branded Phones and Chinese Phones

\begin{tabular}{cl}
\hline Proactive Marketing & \multicolumn{1}{c}{ Branded Phones } \\
\hline Exhibition & Nexian, Beyond, Cross, Blue Berry, HT, LG, Motorolla, Nokia, Sonny Erricson, \\
& Samsung \\
Internet & Nexian, Beyond, Cross, Blue Berry, HT \\
Sponsorship & Nexian, Beyond, Cross, Blue Berry, HT \\
\hline
\end{tabular}

Source: Bandung city cellphone vendor

Based on the table above, in terms of proactive marketing, Chinese cell phones do more proactive marketing through the internet and sponsorship than branded cellphones. This shows that Chinese cell phones are more intensive in marketing than branded cellphones so that they have the opportunity to dominate the market, especially in Indonesia.

In achieving competitive advantage in conditions of rapid and uncertain environmental changes such as environmental changes in mobile business competition as described above, a mobile business organization must be able to create, communicate and deliver superior customer value. Bennett and Smith (2002: 75) argue that competitive advantage can be assessed from the cost (cost) and benefit (benefit). This cost is related to the cost advantage of the company and the price set by the company. Meanwhile, according to Köksal and Özgül (2009: 21) competitive advantage can be seen from the product and service. The product has a very important meaning in a business where it is the point of device for the possibility of success or failure of the overall marketing policy. The product itself is very easy to recognize because everyone uses it all the time, even though the meaning of the product itself is very broad because it is not only the physical form of the product but also includes everything that is non-physical. Service is a form of service provided to customers so that customers can enjoy the services offered.

Based on the description of competitive advantage above, it can be argued that if the company is able to provide superior customer value, which means that the company can provide superior customer value, the company image will be created by itself in the minds of customers. High or superior customer value will give a high image too. This of course will increase the company's competitive advantage. Conversely, low customer value will provide a bad image for the company which results in a decrease in the company's competitive advantage. Thus the achievement of superior customer value is also intended to increase competitive advantage to achieve superior marketing performance or superior marketing performance (Mok \& Man, 2009: 45). Marketing performance is influenced by the size of sales, market share and increased sales (Ferdinand, 2003) and also profitability. Sales volume is the number or number of sales achieved during a certain period. Sales volume is a benchmark for companies to measure the extent to which marketing performance has been achieved superior (Mok \& Man, 2009: 45).

In terms of the mobile phone business phenomenon in Indonesia, especially in the city of Bandung, the application of relationship marketing which is intended to build customer value has not in fact increased competitive advantage optimally. This is evidenced by the rise of Chinese brand cellphones, represented by Nexian and HT Mobile, which are able to shift well-known brands such as Sonny Ericsson or Motorola, which were the most prominent mobile phones at that time, even now Nokia's dominance is threatened by its presence Chinese cell phones. Apart from that, due to the inadequate application of relationship marketing, the marketing performance has not been as expected by the company engaged in the mobile phone sector. Therefore, this study discusses the "influence of relationship marketing and competitive advantage on marketing performance (Survey on Mobile Subscribers in Bandung)". The formulation of the problem in the research is as follows:

1) How much influence does relationship marketing have on marketing performance?

2) How much influence does competitive advantage have on marketing performance?

3) How much influence does relationship marketing have on marketing performance? 


\section{LITERATURE REVIEW}

\section{A. Relationship Marketing and Marketing Performance}

Relationship Marketing is all direct marketing activity to build and enhance and maintain exchanges based on successful relationships. Sheth et al.(2001: 5) argues that relationship marketing leads to any marketing activity that is directed in order to create long-term relationships with customers well. Similar to the above definition, Morgan and Hunt (2004) illustrate the difference between transaction exchanges and relational exchanges. Morgan and Hunt (2004) provide a definition for overall marketing activities that are directed through forming, developing and maintaining successful exchange relationships. Relationship marketing pays attention to improving and maintaining long-term relationships and benefits for both parties

Marketing performance is essentially the result obtained by an agency in terms of marketing performance. Marketing performance is a construct or factor commonly used to measure the impact of a company's strategy. Pelham (1997) argues that marketing performance is the output obtained by the organization where the products sold were previously sold or not in the market. According to Ferdinand (2003) explains that marketing performance depends on what the strategy is developed for, because the purpose of the marketing strategy is more effective and efficient allocation and coordination of resources. The strategy that can be applied is relationship marketing. Therefore, marketing performance is influenced by relationship marketing.

Several studies strongly support that relationship marketing has a positive impact on marketing performance. This opinion is reinforced by research by Kung'a (2016) which states that relationship marketing has a positive impact and influence on sales performance. Furthermore, Abd Ghani et al. (2016) states the same thing that relationship marketing has an impact on marketing effectiveness.

H1: Relationship Marketing has a positive and significant influence on marketing performance

\section{B. Competitive Advantage and Marketing Performance}

Competitive advantage is an advantage achieved through superior customer value by creating a competitive strategy to achieve profit and growth (Bennett \& Smith, 2002: 75). According to Christensen (2010: 21), competitive advantage is any business value provided to motivate customers (or end users) to buy a product or service rather than its competitors. Competitive advantage can be exercised through reducing costs, developing better products, and providing better service to customers in the export market by making the necessary investments in the export process (Köksal \& Özgül, 2009: 21). Competitive advantage comes from innovation, reputation architecture, and strategic asset control.

In his research, Salam (2009) shows that competitive advantage has a positive influence on company performance. Zhou et al. (2009) also provide the same results where competitive advantage has a positive influence on organizational performance as measured by market performance. Furthermore, Dyer and HaBrookshire (2009) operationalize competitive advantage into the components of cost advantages, product advantage and service advantage and their research results show that the three components of competitive advantage have a positive and significant effect on performance. Meanwhile, Gerald and David (2001) determined the competitive advantage over the components of the product strategy, positioning strategy, service and distribution strategy of the company's performance as measured by comparison with competitors in terms of profit and market share. The results of his research indicate that these components have a positive effect on business performance. According to Bharadwaj (2002:153) marketing performance with the right characteristics will produce a sustainable competitive advantage. Referring to the opinion of Crown (2001: 159), Heizer and Render (2000), Salam (2009), Zhou et al. (2009), Dyer and Ha-Brookshire (2009), Gerald and David (2001) so that competitive advantage has an effect on increased marketing performance. Based on the literature above, the following hypothesis was developed:

H2: Competitive advantage has a positive and significant effect on marketing performance

Furthermore, with regard to the research question how to simultaneously influence relationship marketing and competitive advantage on marketing performance, the hypothesis put forward is as follows:

H3: Relationship marketing and competitive advantage have a positive and significant effect on marketing performance 


\section{RESEARCH METHODOLOGY}

The research method used is descriptive verification method. Descriptive method is used to describe the variables and the main characteristics of the respondents. Meanwhile, the verification method is used in testing the hypotheses proposed in the study. The sample used was 35 mobile phone subscribers obtained from purposive sampling technique. The data analysis technique used for data processing is multiple regression analysis by looking for the effect value of the relationship marketing variable and the competitive advantage variable and the marketing performance variable.

\section{IV.RESULT AND DISCUSSION}

Multiple regression analysis is a statistical method to determine the relationship between independent variables and dependent variables. The independent variable in this research is relationship marketing and competitive advantage, while the dependent variable is marketing performance. The purpose of regression analysis is to determine the significance of the independent and dependent variables.

Table 2. Results of Multiple Regression Analysis

\begin{tabular}{|c|c|c|c|c|c|c|}
\hline & \multirow{2}{*}{ Model } & \multicolumn{2}{|c|}{ Unstandardized Coefficients } & \multirow{2}{*}{$\begin{array}{c}\text { Standardized Coefficients } \\
\text { Beta } \\
\end{array}$} & \multirow[b]{2}{*}{$\mathrm{t}$} & \multirow{2}{*}{ Sig. } \\
\hline & & $\mathrm{B}$ & Std. Error & & & \\
\hline \multirow{3}{*}{1} & (Constant) & $-5,587$ & 1,533 & & $-3,646$ & ,001 \\
\hline & $\mathrm{X} 1$ &, 113 & ,098 & , 106 & 6,159 & ,003 \\
\hline & $\mathrm{X} 2$ & ,400 &, 042 & ,872 & 9,532 & ,000 \\
\hline
\end{tabular}

a. Dependent Variable: Y

From the data above, the multiple regression model is obtained: $Y=-5,587+0,113 \mathrm{X}_{1}+0,400 \mathrm{X}_{2}$. From the model above, $0.113 \mathrm{X} 1$ is an independent variable, namely relationship marketing and competitive advantage which have a positive correlation with marketing performance. The constant value of marketing performance is 5.587, indicating that marketing performance is influenced by relationship marketing and competitive advantage. Relationship marketing has an impact on marketing performance valued at $0.113 \mathrm{X} 1$, while at $0.400 \mathrm{X} 2$ competitive advantage has an impact on marketing performance. On the basis of the multiple regression model above, relationship marketing and competitive advantage have a positive value, meaning that it can improve marketing performance.

\section{A. Partial Test}

Testing on the $t$ statistical value is testing the significance of parameters that can contain correct predictions. The $t$ statistic value illustrates the extent to which the independent variables individually influence the dependent variable. If $\mathrm{t}$-count $>\mathrm{t}$-table, it can be concluded that this variable has a significant effect or vice versa, $\mathrm{t}$-count $<\mathrm{t}$ table so that the variable has no significant effect. Therefore it can be reviewed in the table below.

Table 3 Partial Test $\mathrm{t}$

\begin{tabular}{ccccccc}
\hline \multirow{2}{*}{ Model } & \multicolumn{2}{c}{ Unstandardized Coefficients } & \multicolumn{2}{c}{ Standardized Coefficients } & \multirow{2}{*}{ t } & \multirow{2}{*}{ Sig. } \\
\cline { 2 - 5 } & B & Std. Error & Beta & $-3,646$ &, 001 \\
1 & (Constant) & $-5,587$ & 1,533 & & 6,159 &, 003 \\
& $\mathrm{X} 1$ &, 113 &, 098 &, 106 & 9,532 &, 000 \\
\hline
\end{tabular}

a. Dependent Variable: Y

In the partial test (t), it can be seen that relationship marketing has a probability (sig) of $0.03<0.05$, which can be concluded that Ho is not accepted and Ha is accepted. Thus, relationship marketing has a significant effect on marketing performance. Meanwhile, competitive advantage has a probability value (sig) of $0.00<0.05$, so it can be said that Ho is not accepted and $\mathrm{Ha}$ is not rejected. Therefore, competitive advantage has a significant impact on marketing performance. 
Therefore, it can be concluded that the $t$ test of the effect of relationship marketing and competitive advantage on marketing performance obtained a significance value $<0.05$, therefore the hypothesis that relationship marketing and competitive advantage have a significant impact on marketing performance is partially accepted.

\section{B. Simultaneous Test}

This test is carried out in order to prove the simultaneous effect of relationship marketing and competitive advantage on marketing performance. On the basis of these results can be reviewed in table 4 .

Table 4. Simultaneous Test F

\begin{tabular}{llccccc}
\hline \multicolumn{1}{c}{ Model } & Sum of Squares & df & Mean Square & F & Sig. \\
\hline Regression & 1135,214 & 2 & 567,607 & 221,698 &, $000^{\mathrm{b}}$ \\
Residual & 81,929 & 32 & 2,560 & & \\
\hline
\end{tabular}

a. Dependent Variable: Y

b. Predictors: (Constant), X2, X1

From the calculated $\mathrm{F}$ value of 221.698 and a significance of 0.000 . After obtaining F-table then comparing it with the F-count value. If F-count> F-table, the alternative hypothesis is rejected, otherwise if F-count> F-table then the null hypothesis is not rejected, which means the alternative hypothesis is rejected. F-table obtained by 3.159. Thus, the results of the study show F-count $>$ F-table with a value of 185.788> 3.159, which means that H0 is rejected and $\mathrm{Ha}$ is accepted. Therefore, relationship marketing and competitive advantage simultaneously have an impact on marketing performance.

\section{Coefficient of Determination}

The coefficient of determination $(\mathrm{Kd})$ is the coefficient used and serves to determine the value of the contribution of relationship marketing and competitive advantage, which is the independent variable on changes in marketing performance as the dependent variable, through squaring the correlation coefficient (R) and then multiplying it by $100 \%$. Below is the result of the coefficient of determination.

Table 5. Result of the coefficient of determination

\begin{tabular}{ccccc}
\hline Model & $\mathrm{R}$ & R Square & Adjusted R Square & Std. Error of the Estimate \\
\hline 1 &, $966^{\mathrm{a}}$ &, 933 &, 928 & 1,60008 \\
\hline
\end{tabular}

a. Predictors: (Constant), X2, X1

Based on the results of data calculations, it can be seen that the coefficient of determination is 0.933 . Therefore, the impact contribution of relationship marketing and competitive advantage to marketing performance is $93.3 \%$. The results of the above calculations mean that the amount of contribution or influence provided by relationship marketing and competitive advantage on marketing performance is $93.3 \%$, the remaining $6.7 \%$ is influenced by other factors that affect marketing performance, but research by the authors between others price, advertising, and others.

\section{Discussion}

The results of this study illustrate that relationship marketing and competitive advantage have a positive and significant effect on marketing performance. Relationship marketing has the greatest influence with a t-count of 6.159 while competitive advantage has an influence with a t-count of 9.532. For the t-test of relationship marketing, the value ( $\mathrm{sig}$ ) is $0.03<0.05$, so that Ho is not accepted and Ha is accepted. Therefore, the hypothesis which says there is a positive and significant effect of relationship marketing on marketing performance is accepted. The results of this study are in accordance with the results of research from Kung'a (2016) which states that relationship marketing has a positive impact and influence on sales performance. Furthermore, Abd Ghani $e t$ al. (2016) states the same thing that relationship marketing has an impact on marketing effectiveness. Therefore, relationship marketing has a positive impact on improving marketing performance. Meanwhile, the $t$ test for competitive advantage has a value ( $\mathrm{sig}$ ) of $0.00<0.05$, thus it can be concluded that Ho is not accepted and Ha is not rejected. Therefore, the hypothesis which describes a positive and significant effect of competitive advantage on marketing performance is accepted. This result is in accordance with the results of Li's research (2000: 313) which states that there is a positive impact on competitive advantage with performance as assessed by the size of sales, profits, market share, and ROI. Then, Droge et al.(2005) stated that competitive advantage can have an 
influence on the company's market performance as assessed through customer growth. Furthermore, the results of the study illustrate that relationship marketing and competitive advantage have simultaneous influence on marketing performance of 221.698. Then seen from the level of relationship, the variable relationship marketing and competitive advantage in marketing performance has a correlation level of 0.966 , which means it has a very high level of relationship. Meanwhile, seen from the magnitude of the coefficient of determination, $93.3 \%$ relationship marketing and competitive advantage have an influence on marketing performance, the remaining $6.7 \%$ is influenced by other factors. Therefore, relationship marketing and competitive excellence have a positive influence on improving marketing performance.

\section{CONCLUSION}

The results of research on the effect of relationship marketing and competitive advantage on marketing performance can be concluded that there is an effect of relationship marketing on marketing performance. This illustrates that the better relationship marketing is, the marketing performance will increase. Then the results of subsequent research indicate that there is an effect of competitive advantage on marketing performance. These results indicate that the more superior in the competition, the more marketing performance increases. Meanwhile, the results of the research simultaneously state that there is an effect of relationship marketing and competitive advantage on marketing performance together. This indicates that the better the relationship marketing and the competitive advantage, the higher the marketing performance.

On the basis of the results of research on the effect of relationship marketing and competitive advantage on marketing performance, we recommend that mobile phone vendors increase their relationship marketing activities to achieve optimal marketing performance. Furthermore, companies need to maintain and even increase their competitive advantage through these mobile product innovations. Apart from that, further improve marketing performance by increasing product competitiveness and also improving customer service.

\section{REFERENCES}

Abd Ghani, M., Othman, A., Ibrahim, N. A., \& Ismail, W. Z. W. (2016) 'Relationship marketing practices and effects on marketing effectiveness: An empirical insight from the hotel industry', International Review of Management and Marketing, 6(4).

Bennet, R. dan Smith, C. (2002) 'Competitive, Conditions, Competitive Advantage and The Location of SME's', Journal of Small Business and Enterprise Development Vol 9:2. MCB University Press.pp.73-86.

Bharadwaj, Sundar G, P.R.Varadarajan, \& Fahly, Jihn. (2003) 'Sustainable Competitive Advantage in Service Industries: A Conceptual Model and Research Propositions', Journal of Marketing. Vol.57,October, p.8399.

Bharadwaj, A. S., Bharadwaj, S. G., \& Konsynski, B. R. (2002). Information Technology Effects on Firm Performance as Measured by Tobin's q. Management Science, 45(7), 1008-1024.

Christensen. (2009) 'Defining customer value as the driver of competitive advantage', Journal Strategy and Leadership Vol. 38 No. 5 2010, pp. 20-25,

Droge, C., Vickery, S.K., (2005) 'The Impact of Human Resource Management Practice on Performance', Journal of Operations Management

Dyer, B., \& Ha-Brookshire, J. E. (2009) 'Apparel import intermediaries' secrets to success', Journal of Fashion Marketing and Management: An International Journal, 12(1), 51-67.

Ferdinand, August, (2003) 'Keunggulan Diferensiasif', Jurnal Bisnis Strategi Vol. 12 (Desember). pp. 1-15.

Gerald and Tse K David,(2001),Adaptation of International MarketingStrategy Components, Competitive Advantage, and Firm Performance:A Study of Hong Kong Exporters, Journal of International MarketingVol. 9, No. 4, 2001, pp. 59-61

Heizer, Jay., \& Barry Render, 2000, Operation Management. New Jersey: Pearson Education, Inc. $7^{\text {th }}$ Editions

Köksal, M. H., \& Özgül, E, (2009) 'The export competitive advantages of Turkish manufacturing companies', Journal Marketing Intelligence \& Planning, Vol. 28 No. 2, 2010 pp. 206-222

Kotler, Philip dan Keller, Kevin Lane. (2009) Marketing Management. New Jersey: Pearson Education International.Schultz 
Kung'a, A. B. (2016) 'The influence of Relationship Marketing on Sales Performance in the Telecommunication Industry in Kenya', (Doctoral dissertation, University Of Nairobi).

Li, Ling X. (2000) 'An Analysis of Sources of Competitiveness and Performance of Chinese Manufacturers', International Journal of Operation and Production Management Vol. 20 No.3.

Mok, Mandy \& Man, Kim, (2009) 'The Relationship between Distinctive Capabilities, Innovativeness Strategy Types and the Export Performance of Small and Medium-Size Enterprises (SMEs) of Malaysian Manufacturing Sector', Journal of Management and Innovation, Vol. 2. No. 1.

Morgan, R. M., \& Hunt, S. D. (2004) 'The Commitment-Trust Theory of Relationship Marketing', Journal of Marketing, Vol. 58. No. 3. pp: 20-38.

Nagasimha, Kanagal. (2008) 'Role of Relationship Marketing in Competitive Marketing Strategy', Journal of Management and Marketing Research.

Pelham, Alfred. (1997) 'Mediating Influences on The Relationship Between Market Orientation and Profitability in Small Industry Firms', Journal of Marketing Theory and Practice, Summer, 55-75.

Salam, S. (2009) 'Leadership and Teamwork: The Effects of Leadership and Job Satisfaction on Team Citizenship', International Journal of Leadership Studies, Vol. 2, h. 171-193

Sheth, Jagdish N and Mittal, Banwari. (2001) Customer Behaviour: Managerial Perspective. Second Edition. Singapore: Thomson.

Zhou, K. Z., Brown, J. R., and Dev, C. S. (2009) 'Market orientation, competitive advantage, and performance: a demand-based perspective', Journal of Business Research, 2009, Vol. 62 No. 11, pp. 1063-1070. 